\title{
Gorontalo
}

Journal of Public Health

Volume 3 - No. 1 - April 2020

P-ISSN: 2614-5057, E-ISSN: 2614-5065

\section{Hubungan Pola Konsumsi Ikan dengan Status Gizi \\ Anak Sekolah di Pesisir Teluk Pandan \\ Kabupaten Pesaweran}

\section{Correlation Fish Consumption Pattern with Nutritional Status in School Children Teluk Pandan, Pesaweran District}

\author{
Sutrio*, Roza Mulyani \\ Jurusan Gizi, Politeknik Kesehatan Tanjung Karang, \\ Kota Bandar Lampung, Indonesia \\ *email: sutrio.syakir@yahoo.com
}

\begin{abstract}
School children are important objectives in improving the nutritional status of society. Nutritional status one of them is influenced by protein consumption. Fish is a good source of protein for the growth period and low fish consumption in elementary school students is a problem caused by various factors. This research was to know the pattern of fish consumption with nutritional status in the school children in the Gulf of Pandan Coastal Regency Pesawaran. Research was used cross-sectional research study. The research was conducted at Teluk Pandan Coast Elementary School in August-September 2019. Samples in this study were children of $V$ and VI classes as many as 111 students. Data analysis using chi-square test.The results was showed that the level of protein intake $(p=0.040)$ was association with the nutritional status while the amount of fish consumption ( $p=$ $0.599)$, the frequency of fish consumption ( $p=0.954)$, the proportion of fish protein consumption $(P=0.076)$ were not related with nutritional status. The school can utilize media such as posters that contain the importance of consuming fish in school children and include material about the importance of protein intake and fish proteins into physical and sports education subjects and campaigning for the "love to eat fish" slogan. Parents make fish processed with a variety of menu variations so that children can prefer fish.
\end{abstract}

Keywords: fish consumption pattern; nutritional status; school children

\begin{abstract}
Abstrak
Anak sekolah merupakan sasaran penting dalam perbaikan status gizi masyarakat. Status gizi salah satunya dipengaruhi oleh konsumsi protein. Ikan merupakan sumber protein yang baik untuk masa pertumbuhan dan rendahnya konsumsi ikan pada siswa Sekolah Dasar merupakan masalah yang disebabkan oleh berbagai faktor. Penelitian ini bertujuan untuk mengetahui hubungan pola konsumsi ikan dengan status gizi pada anak sekolah di Pesisir Teluk Pandan Kabupaten Pesawaran. Penelitian menggunakan rancangan penelitian cross sectional. Penelitian ini dilakukan di SDN Pesisir Teluk Pandan pada bulan Agustus-September 2019. Sampel pada penelitian ini adalah anak kelas V dan VI sebanyak 111 siswa. Analisa data menggunakan uji chi-square test. Hasil penelitian menunjukkan ada hubungan antara tingkat asupan protein $(\mathrm{p}=$ 0.040) dengan status gizi dantidak ada hubungan yang bermakna antara jumlah konsumsi ikan $(p=0.599)$, frekuensi konsumsi ikan $(p=0.954)$, proporsi
\end{abstract}


konsumsi protein ikan $(\mathrm{p}=0.076)$ dengan status gizi. Pihak sekolah dapat memanfaatkan media seperti poster yang berisikan tentang pentingnya mengonsumsi ikan pada anak sekolah dan memasukkan materi tentang pentingnya asupan protein dan protein ikan kedalam mata pelajaran pendidikan jasmani dan olahraga serta mengkampanyekan kembali slogan "gemar makan ikan". Orang tua murid membuat olahan ikan dengan berbagai variasi menu sehingga anak lebih bisa menyukai ikan.

Kata kunci: pola konsumsi ikan; status gizi; anak sekolah

\section{PENDAHULUAN}

Beragam masalah gizi dijumpai diberbagai negara berkembang, contohnya di Indonesia. Berdasarkan buku saku PSG (2017), menunjukkan secara nasional prevalensi kurus (menurut IMT/U) pada anak umur 5-12 tahun adalah 10,9\%, terdiri dari $3,4 \%$ sangat kurus dan $7,5 \%$ kurus. Secara nasional masalah stunting pada anak umur 5-12 tahun masih tinggi yaitu 27,7\%, terdiri dari sangat pendek 8,3\% dan pendek 19,4\% (Kemenkes, 2017).

Pola konsumsi masyarakat Indonesia terhadap sumber pangan hewani terutama ikan masih rendah. Pada tahun 2017 target rata-rata konsumsi ikan $47 \mathrm{~kg}$ atau sekitar 128 gram/kapita/hari, namun konsumsi ikan di masyarakat masih dibawah target yaitu $37,30 \mathrm{~kg}$ per tahun atau sekitar 102,19 gram/kapita/hari. Tahun 2018, target konsumsi ikan nasional 50,65 $\mathrm{kg} / \mathrm{kapita} /$ tahun atau 138 gram/hari sedangkan rata-rata konsumsi ikan di masyarakat 39,57 kg/kapita/tahun atau sekitar 108,41 grm/kapit/hari. Pada tahun 2018 angka konsumsi ikan Provinsi Lampung mencapai angka 33,05 $\mathrm{kg} /$ kapita namun demikian angka tersebut masih rendah dibandingkan target nasional sebesar $54,49 \% \mathrm{~kg} /$ kapita meskipun demikian tingkat konsumsi ikan Provinsi Lampung terus mengalami peningkatan setiap tahunnya dengan pertumbuhan sebesar 7,82\% (Kementerian Kelautan dan Perikanan, 2018).

Hingga saat ini, pola konsumsi masyarakat Indonesia terhadap sumber pangan hewani secara umum masih rendah jika dibandingkan dengan pangan nabati. Pada tahun 2014, konsumsi protein hewani sebesar 32,1\% dari total protein. Konsumsi protein hewani nasional masih sangat rendah dan perlu terus ditingkatkan. Rendahnya konsumsi protein tersebut berpotensi menghambat upaya peningkatan kualitas sumberdaya manusia Indonesia (Badan Pusat Statistik, 2014).

Pangan sumber protein hewani meliputi daging, telur, susu, ikan, seafood dan hasil olahannya. Menurut WNPG (2012) dalam Hardinsyah dkk, (2012) sumbangan protein hewani dianjurkan sebesar 25 persen dari total angka kecukupan protein (AKP). Dari angka tersebut, porsi ikan diharapkan lebih banyak dalam pemenuhan kebutuhan protein hewani yaitu sekitar $60 \%$ (Hardinsyah dkk, 2012).

Ikan laut merupakan salah satu jenis pangan hewani yang memiliki kandungan protein yang sempurna. Semua asam amino dalam jumlah yang mencukupi kebutuhan tubuh terkandung di dalamnya. Selain itu, ikan juga memiliki kandungan asam lemak omega-3 yang diketahui dapat menurunkan kadar kolesterol darah. Potensi perikanan di Provinsi Lampung cukup berlimpah dengan luas perairan laut (12 mil) $24.820,0 \mathrm{~km}^{2}(41,2 \%)$ dari total luas keseluruhan termasuk di dalamnya luas perairan pesisir $16.625,3 \mathrm{~km}^{2}$. Produksi perikanan tangkap didominasi oleh ikan hasil tangkapan perikanan laut $(95,75 \%)$ dan sisanya dari perairan umum. Sementara produksi perikanan tangkap tahun 2018 mencapai 142.543 ton (perairan umum sebesar 6.054 ton dan produksi laut sebesar 136.489 ton). Sedangkan untuk potensi lahan budidaya di Provinsi Lampung sebesar 325.330,27 hektar. Dengan sumber daya 
yang melimpah tersebut, Lampung diharapkan dapat berkontribusi dalam pemenuhan kebutuhan protein hewani (DKP Provinsi Lampung, 2018).

Laporan hasil penjaringan anak SD/MI Puskesmas Hanura (2018) didapatkan data status gizi siswa tertinggi dengan kategori kurus dan sangat kurus ada di SDN 4 (13,4\%) dan SDN 14 Teluk Pandan (11,7\%). SDN 4 dan SDN 14 Teluk Pandan terletak di sepanjang pesisir Teluk Pandan yang memiliki karakteristik yang sama karena sebagian besar orang tua murid adalah bermata pencaharian nelayan dan memiliki potensi laut yaitu hasil tangkap ikan laut. Kondisi alam ini sangat mendukung program peningkatan konsumsi ikan dalam rangka upaya peningkatan sumberdaya manusia. Sampai saat ini belum ada penelitian konsumsi ikan anak usia sekolah di Pesisir Teluk Pandan Kabupaten Pesawaran. Sehingga tujuan penelitian ini mengetahui hubungan pola konsumsi ikan dengan status gizi anak sekolah di pesisir Teluk Pandan.

\section{METODE}

Penelitian ini merupakan penelitian kuantitatif yang menggunakan desain studi cross sectional. Populasi dalam penelitian ini adalah seluruh anak SDN 4 dan SDN 14 Pesisir Teluk Pandan. Sampel dalam penelitian ini adalah total populasi kelas 5 dan 6 yaitu berjumlah 111 anak. Teknik pengambilam sampel pada penelitian ini menggunakan total sampling atau sampling jenuh.

Variabel penelitian meliputi status gizi, tingkat asupan protein, jumlah konsumsi ikan, frekuensi konsumsi ikan, dan proporsi konsumsi Ikan. Status gizi diukur berdasarkan rekomendasi WHO Antro Plus menggunakan indikator IMT/U. Kategori tingkat konsumsi protein dibagi menjadi 4 yaitu sangat kurang ( $\leq 80 \%$ dari AKG), kurang $(80 \%-<100 \%$ dari AKG), normal $(100-<120 \%$ dari AKG), dan lebih ( $\geq 120 \%$ dari AKG) (Depkes, 1990 dalam Supariasa dkk, 2016). Jumlah konsumsi ikan dibagi menjadi dua yaitu kurang apabila kurang dari $71,2 \mathrm{~g} /$ hari dan cukup apabila lebih atau sama dengan 71,2 $\mathrm{g} /$ hari (Departemen Kelautan dan Perikanan Republik Indonesia, 2004). Frekuensi ikan dibagi menjadi empat yaitu tidak pernah, jarang (1-2 kali dalam seminggu), sering (4-6 kali dalam seminggu), dan setiap hari (Purnamasari, 2018). Proporsi konsumsi ikan dibagi menjadi dua yaitu kurang (<60\% dari anjuran) dan cukup ( $\geq 60 \%$ dari anjuran) (Hardiansyah dkk, 2012). Pada penelitian ini pengumpulan data dilakukan dengan wawancara secara langsung menggunakan kuisioner.

Instrumen yang digunakan dalam penelitian ini adalah microtoise untuk mengukur tinggi badan anak sekolah, timbangan badan untuk mengukur IMT, kuisioner untuk mengetahi identitas responden dan frekuensi konsumsi ikan, formulir food recall untuk mengukur tingkat konsumsi protein, tingkat konsumsi ikan dan proporsi konsumsi protein ikan sedangkan food record untuk mengukur jumlah ikan yang dikonsumsi selama 7 hari beturut-turut.

Analisis data meliputi analisis univariat dan analisis bivariat. Analisis data status gizi menggunakan aplikasi WHO Antro Plus 2010 untuk mendapatkan status gizi anak sekolah, sementara analisis data penelitian secara keseluruhan menggunakan aplikasi statistical package for social science (SPSS). Analisis untuk memberikan gambaran dari masing-masing variabel. Analisis bivariat digunakan untuk menilai hubungan antara variabel jumlah tingkat konsumsi protein, jumlah konsumsi ikan, frekuensi konsumsi ikan, dan proporsi konsumsi ikan dengan status gizi anak sekolah dengan menggunakan uji chisquare $(\mathrm{a}=0,05)$. 
HASIL DAN PEMBAHASAN

Karakteristik Subjek Penelitian

Gambaran Karakteristik umur, jenis kelamin, mata pencaharian orang tua pada responden ditunjukkan pada Tabel 1. Karakteristik umur paling banyak pada umur 11 tahun yaitu 46 anak $(41,4 \%)$ dan terendah pada umur 12 tahun yaitu 20 orang $(18,1 \%)$. Untuk distribusi jenis kelamin anak sekolah proporsi tertinggi pada anak perempuan yaitu 71 orang (64\%) dan terendah pada lakilaki yaitu 40 orang $(36 \%)$. Distribusi pekerjaan orang tua lebih tinggi sebagai nelayan yaitu 54 orang $(57,6 \%)$ dan tersendah sebagai PNS yaitu 5 orang $(4,5 \%)$.

Tabel 1. Gambaran Karakteristik, Umur, Jenis Kelamin dan Mata Pencaharian Orang Tua Responden

\begin{tabular}{lcc}
\hline \multirow{2}{*}{ Karakteristik } & \multicolumn{2}{c}{ Jumlah } \\
\cline { 2 - 3 } & $\mathrm{n}$ & $\%$ \\
\hline Umur & & \\
10 tahun & 45 & 40,5 \\
11 tahun & 46 & 41,4 \\
12 tahun & 20 & 18,1 \\
Jenis Kelamin & & \\
Laki & 40 & 36 \\
Perempuan & 71 & 64 \\
Mata Pencaharian & & \\
Nelayan & 54 & 57,6 \\
Buruh & 40 & 27,1 \\
PNS & 5 & 4,5 \\
Tani & 12 & 10,8 \\
\hline
\end{tabular}

\section{Analisis Hubungan Pola Konsumsi Ikan dengan Status Gizi Anak Sekolah}

Tabel 2 menunjukkan ada hubungan tingkat asupan protein dengan status gizi $(\mathrm{p}=0,040)$, tidak ada hubungan yang bermakna antara jumlah konsumsi ikan $(p=0,599)$, frekuensi konsumsi ikan $(p=0,954)$, dan proporsi konsumsi protein ikan $(\mathrm{p}=0,076)$ dengan status gizi pada anak sekolah.

Tabel 2.Analisis Hubungan Tingkat Asupan Protein, Jumlah Konsumsi Ikan,

Frekuensi Konsumsi Ikan dan Proporsi Konsumsi Ikan dengan Status Gizi

\begin{tabular}{|c|c|c|c|c|c|c|c|}
\hline \multirow{3}{*}{ Variabel Independen } & \multicolumn{4}{|c|}{ Status Gizi } & \multirow{2}{*}{\multicolumn{2}{|c|}{ Total }} & \multirow{3}{*}{$\begin{array}{c}p- \\
\text { value }\end{array}$} \\
\hline & \multicolumn{2}{|c|}{$\begin{array}{c}\text { Tidak } \\
\text { Normal }\end{array}$} & \multicolumn{2}{|c|}{ Normal } & & & \\
\hline & $\mathrm{n}$ & $\%$ & $\mathrm{n}$ & $\%$ & $\mathrm{~N}$ & $\%$ & \\
\hline \multicolumn{8}{|l|}{ Asupan Protein } \\
\hline Kurang & 17 & 36,2 & 30 & 63,8 & 47 & 42,3 & 0,040 \\
\hline Cukup & 11 & 17,2 & 53 & 82,8 & 64 & 57,7 & \\
\hline \multicolumn{8}{|c|}{ Jumlah Konsumsi Ikan } \\
\hline Kurang & 26 & 24,5 & 80 & 75,5 & 106 & 95,5 & 0,599 \\
\hline Cukup & 2 & 40 & 3 & 60 & 5 & 0,5 & \\
\hline \multicolumn{8}{|c|}{ Frekuensi Konsumsi Ikan } \\
\hline Tidak Baik & 14 & 26,4 & 39 & 73,6 & 53 & 47,7 & 0,954 \\
\hline Baik & 14 & 24,1 & 44 & 75,9 & 58 & 53,3 & \\
\hline \multicolumn{8}{|c|}{ Proporsi Konsumsi Protein Ikan } \\
\hline Kurang & 23 & 31,1 & 51 & 68,9 & 74 & 66,6 & 0,076 \\
\hline Cukup & 5 & 13,5 & 32 & 86,5 & 37 & 33,4 & \\
\hline Total & 28 & 25,2 & 83 & 74,8 & 111 & 100 & \\
\hline
\end{tabular}


Hasil statistik menunjukkan ada hubungan yang bermakna antara asupan protein dengan status gizi berdasarkan IMT/U yang ditunjukkan dengan $p$-value 0,040 ( $p$-value $<0,05$ ). Uji statistik juga menghasilkan nilai odds ratio (OR) yaitu 2,730 yang berarti siswa dengan asupan protein kurang, berisiko 2,730 kali status gizinya menjadi tidak normal dibandingkan dengan siswa yang tingkat kecukupan proteinnya cukup. Status gizi anak sekolah dasar dapat dipengaruhi oleh banyak faktor diantaranya adalah tingkat kecukupan energi dan protein. Ketidakseimbangan tingkat kecukupan energi dan protein, kemungkinan dapat menyebabkan masalah gizi pada anak. Protein merupakan salah satu zat gizi yang dapat mempengaruhi keadaan status gizi seseorang. Berdasarkan penelitian yang dilakukan, didapatkan hasil bahwa asupan protein kurang cenderung lebih banyak terjadi pada anak dengan status gizi dengan kategori tidak normal meskipun ada juga tingkat asupan proteinnya cukup tetapi masih ada yang status gizinya tidak normal $(17,2 \%)$ dikarenakan untuk mecapai status gizi yang normal tidak hanya cukup dari protein saja tetapi asupan zat gizi lain seperti karbohidrat dan lemak sebagai zat pembangun dan zat pengatur dalam tubuh menunjang pertumbuhan serta membutuhkan vitamin dan mineral dari sayur dan buah.

Hal ini serupa dengan penelitian Junaidi (2007), yang menunjukkan bahwa asupan protein pada anak dengan status gizi kategori kurus lebih rendah dibandingkan dengan anak dengan status gizi normal. Selain itu anak dengan asupan makanan yang cukup maupun kurang dapat memiliki status gizi kurang. Pada penelitian lain yang dilakukan oleh Nagari dan Nindya (2017) menyatakan bahwa anak yang memiliki status gizi kurus memiliki tingkat kecukupan protein yang kurang, sedangkan untuk anak dengan tingkat kecukupan protein normal menyebabkan anak memiliki status gizi normal atau gemuk. Penelitian ini diperkuat dengan penelitian yang dilakukan oleh Regar dan Sekartini (2012) tentang status gizi anak di Kelurahan Kampung Melayu, Jakarta Timur bahwa terdapat hubungan antara asupan protein dengan status gizi anak. Sedangkan menurut penelitian yang dilakukan oleh Monica dkk, (2015) tentang faktor-faktor yang berhubungan dengan pola konsumsi ikan siswa Sekolah Dasar Negeri 060919 di Kecamatan Medan Sunggal, terdapat anak dengan status gizi baik namun dengan asupan konsumsi protein yang kurang.

Protein merupakan zat yang sangat penting bagi setiap organisme serta merupakan komponen terbesar dari semua sel hidup. Protein dalam tubuh berfungsi sebagai sumber utama energi selain karbohidrat dan lemak, sebagai zat pembangun dan zat pengatur dalam tubuh (Diana, 2009). Berdasarkan asalnya protein dibedakan mejadi dua, yaitu protein nabati dan protein hewani. Protein nabati berasal dari tumbuhan misalnya kacang - kacangan, tahu, tempe, oncom, dan kecap. Protein hewani berasal dari hewan misalnya ikan, daging ayam, daging sapi, keju, cumi-cumi, udang, dan telur (Devi, 2010). Protein hewani memiliki susunan asam amino yang lebih kompleks dari pada susunan asam amino pada protein nabati (Diana, 2009). Protein hewani juga memiliki mutu cerna yang tinggi sehingga jumlah yang dapat diserap ke dalam tubuh juga tinggi, salah satu cara mendapatkan protein hewani adalah dengan mengkonsumsi ikan. Ikan merupakan bahan pangan sumber protein hewani yang mempunyai komposisi gizi cukup lengkap, oleh sebab itu ikan sangat penting bagi kebutuhan manusia, selain harganya relatif murah, ikan mengandung berbagai macam vitamin, mineral dan asam lemak tak jenuh yang sangat diperlukan oleh tubuh (Buckle dkk, 2007).

Hasil uji statistik menunjukkan tidak ada hubungan antara jumlah konsumsi ikan dengan status gizi $(p=0,599, \geq$ nilai a 0,05$)$. Hal ini terjadi 
karena status gizi bukan hanya dipengaruhi langsung dari konsumsi ikan saja tetapi status gizi anak sekolah dasar dapat dipengaruhi oleh banyak faktor diantaranya adalah tingkat kecukupan energi dan protein total. Kecukupan energi dan protein total ini bukan hanya dari ikan saja tetapi dari sumber makanan lain yang beraneka ragam seperti karbohidrat (nasi), protein (protein hewani dan nabati), dan lemak (daging).

Pada hasil penelitian menunjukkan tidak ada hubungan antara frekuensi konsumsi ikan dengan status gizi anak sekolah dasar di sekolah dasar pesisir Teluk Pandan $(p=0,954, \geq$ nilai a 0,05$)$. Meskipun ikan sebagai salah satu sumber zat gizi hasil laut yang memiliki kandungan protein cukup tinggi, susunan asam amino di dalam ikan cukup baik tetapi tingginya frekuensi konsumsi ikan tidak menjamin sesuai dengan jumlah pemenuhan kebutuhan protein ikan pada anak sekolah dan status gizi tidak hanya dipengaruhi oleh frekuensi makan ikan saja akan tetapi juga dipengaruhi oleh total asupan makan. Hasil penelitian ini juga sejalan dengan penelitian Marques et al. (2008) di Amazon yang menyatakan bahwa tingkat konsumsi ikan tidak berdampak signifikan pada pertumbuhan anak.

Rerata asupan protein ikan pada anak sekolah di sekolah dasar pesisir Teluk Pandan adalah 15,749 gram dengan kontribusi protein ikan adalah 65,7\% dari protein total yang dikonsumsi. Hasil uji statistik menunjukkan tidak ada hubungan antara proporsi asupan protein ikan dengan status gizi $(p=0,076, \geq$ nilai a 0,05). Hal ini terjadi karena status gizi bukan hanya dipengaruhi langsung dari asupan protein ikan tetapi status gizi anak sekolah dasar dapat dipengaruhi oleh banyak faktor diantaranya adalah tingkat kecukupan energi dan protein total. Protein total ini bukan hanya dari ikan saja tetapi dari sumber protein lain baik hewani maupun nabati. Sutomo (2008) menyatakan bahwa bahan makanan hewani merupakan sumber protein yang lebih baik dibanding dengan nabati, terutama dilihat dari segi besar kandungan protein per 100 gram bahan makanan maupun dari mutunya. Bahan makanan sumber protein hewani adalah ikan, udang dan makanan hasil laut, daging unggas, telur, susu, dan daging ternak besar (sapi, kambing, kerbau dan lain-lain). Bahan makanan sumber protein nabati adalah, jamur, padi-padian, kacang-kacangan (kedelai, kacang tanah dan lain - lain) serta hasil olahanya (tempe, tahu, oncom dan lain - lain). Ketidakseimbangan tingkat kecukupan energi dan protein, kemungkinan dapat menyebabkan masalah gizi pada anak. Terbukti anak yang berstatus gizi baik/normal mempunyai asupan protein yang baik pula.

\section{PENUTUP}

Berdasarkan hasil penelitian dan pembahasan disimpulkan bahwa ada hubungan antara tingkat asupan protein dengan status gizi dan tidak ada hubungan antara jumlah konsumsi ikan, frekuensi dan proporsi konsumsi ikan dengan status gizi. Pihak sekolah dapat memanfaatkan media seperti poster yang berisikan tentang pentingnya mengkonsumsi ikan pada anak sekolah dan memasukkan materi tentang pentingnya asupan protein dan protein ikan kedalam mata pelajaran Pendidikan Jasmani dan Olahraga serta mengkampanyekan kembali slogan "Gemar Makan Ikan". Orang tua murid membuat olahan ikan dengan berbagai variasi menu sehingga anak lebih bisa menyukai ikan.

\section{DAFTAR PUSTAKA}

Badan Pusat Statistik. 2014. Analisis Rumah Tangga Perikanan di Indonesia. Jakarta: Badan Pusat Statistik.

Buckle KA, Edward RA, Fleet GH, Wootton. 2007. Ilmu Pangan Edisi Ke-4. Terjemahan Hari Purnomo dan Adiono. UI-Press. Jakarta. 
Devi N. 2010. Nutrition and Food. PT Kompas Media Nusantara. Jakarta.

Diana FM. 2009. Fungsi dan Metabolisme Protein dalam Tubuh Manusia. Jurnal Kesehatan Masyarakat Andalas. 4(1): 47 - 52.

Departemen Kelautan dan Perikanan Republik Indonesia (DKP). 2004. Merajut Ikatan "Gemarikan" Dari Daerah ke Daerah melalui Penyuluhan. Jakarta: Departemen Kelautan dan Perikanan Republik Indonesia.

Dinas Kelautan dan Perikanan Propinsi Lampung, 2018. Inventarisasi dan Informasi Pengolahan dan Perikanan Provinsi Lampung 2018. Bandar Lampung: Dinas Kelautan dan Perikanan Propinsi Lampung.

Hardinsyah, Irawati A, Kartono D, Prihartini S, Linorita I, Amilia L, Fermanda M, Adyas EE, Yudianti D, Kusharto CM, Heryanto Y. 2012. Pola Konsumsi Pangan dan Gizi Penduduk Indonesia. Bogor: Departemen Gizi Masyarakat FEMA IPB dan Badan Litbangkes Kemenkes RI.

Junaidi. 2007. Hubungan Keparahan Karies Gigi dengan Konsumsi Zat Gizi dan Status Gizi Anak Sekolah Dasar Di Kecamatan Lhoknga Kabupaten Aceh Besar. Jurnal Gizi Klinik Indonesia. 4(2): 92 - 96.

Kementerian Kesehatan RI. 2017. Buku Saku Pemantauan Status Gizi (PSG). Jakarta: Kementerian Kesehatan RI

Kementerian Kelautan dan Perikanan. 2018. Produktivitas Perikanan Indonesia. Jakarta: Kementerian Kelautan dan Perikanan.

Marques RC, Dorea JG, Bernardi JV, Bastos WR, Malm O. 2008. Maternal Fish Consumption in The Nutrition Transition of The Amazon Basin: Growth of Exclusively Breastfed Infants during The First 5 Years. Ann. Hum. Biol. 35: $363-377$.

Monica A, Jumirah, Siagian A. 2015. Faktor-Faktor yang Berhubungan dengan Pola Konsumsi Ikan Siswa Sekolah Dasar Negeri 060919 di Kecamatan Medan Sunggal. Jurnal USU Gizi, Kesehatan Reproduksi dan Epidemiologi. 1(5): $1-10$.

Nagari RK, Nindya TS. 2017. Tingkat Kecukupan Energi, Protein, dan Status Ketahanan Pangan Rumah Tangga Berhubungan dengan Status Gizi Anak Usia 6-12 Tahun di SD Negeri 1 dan 2 Sambirejo Kecamatan Trenggalek, Kabupaten Trenggalek. Jurnal Kesehatan Masyarakat. Universitas Airlangga. 3: 189 - 197.

Purnamasari DU. 2018. Panduan Gizi Dan Kesehatan Anak Sekolah. Penerbit Andi. Yogyakarta.

Puskesmas Hanura. 2018. Laporan Hasil Penjaringan Anak SD/MI Kecamatan Teluk Pandan. Pesawaran: Puskesmas Hanura.

Regar E, Sekartini R. 2012. Status Gizi Anak di Kelurahan Kampung Melayu, Jakarta Timur. Jurnal Kedokteran Indonesia. 1(3): $184-189$.

Supariasa IDN, Bakri B, Fajar I. 2016. Penilaian Status Gizi. Penerbit Buku Kedokteran EGC. Jakarta.

Sutomo B. 2008. Sukses Wirausaha Kue Kering. Kriya Pustaka. Jakarta.

Widyakarya Pangan dan Gizi X (WNPG). 2012. Pemantapan Ketahanan Pangan Perbaikan Gizi Berbasis Kemandirian dan Kearifan Lokal. 20-21 November. Jakarta. 